\title{
Nanocrystalline p-layer for a-Si:H p-i-n solar cells and photodiodes
}

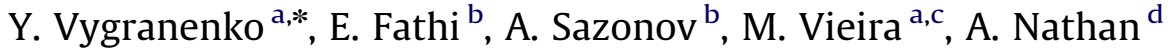 \\ a Electronics, Telecommunications and Computer Engineering, ISEL, Rua Conselheiro Emidio Navarro 1, Lisbon 1949-014, Portugal \\ ${ }^{\mathrm{b}}$ Department of Electrical and Computer Engineering, University of Waterloo, 200 University Avenue West, Waterloo, Canada N2L 3G1 \\ c CTS-UNINOVA, Quinta da Torre, P-2829-516 Caparica, Portugal \\ ' London Centre for Nanotechnology, UCL, 17-19 Gordon Street, London WC1H OAH, United Kingdom
}

\section{A R T I C L E I N F O}

\section{Article history:}

Received 19 November 2009

Received in revised form

13 June 2010

Accepted 22 June 2010

Available online 21 July 2010

Keywords:

Nanocrystalline silicon

Conductivity

PECVD

Solar cell

Photodiode

\begin{abstract}
A B S T R A C T
We report on structural, electronic, and optical properties of boron-doped, hydrogenated nanocrystalline silicon (nc-Si:H) thin films deposited by plasma-enhanced chemical vapor deposition (PECVD) at a substrate temperature of $150{ }^{\circ} \mathrm{C}$. Film properties were studied as a function of trimethylboron-to-silane ratio and film thickness. The absorption loss of $25 \%$ at a wavelength of $400 \mathrm{~nm}$ was measured for the $20 \mathrm{~nm}$ thick films on glass and glass/ZnO:Al substrates. By employing the $\mathrm{p}^{+} \mathrm{nc}-\mathrm{Si}: \mathrm{H}$ as a window layer, complete $\mathrm{p}-\mathrm{i}-\mathrm{n}$ structures were fabricated and characterized. Low leakage current and enhanced sensitivity in the UV/blue range were achieved by incorporating an a-SiC:H buffer between the $\mathrm{p}$ - and i-layers.
\end{abstract}

(c) 2010 Elsevier B.V. All rights reserved.

\section{Introduction}

Boron-doped hydrogenated nanocrystalline silicon (nc-Si:H) is an attractive material for large-area electronics and photovoltaic applications. It has advantages over hydrogenated amorphous silicon (a-Si:H) and silicon carbide with respect to higher conductivity and lower optical absorption in the visible range $[1,2]$. Thin $\mathrm{p}$-type nc-Si:H films are used as the window layer in $\mathrm{p}-\mathrm{i}-\mathrm{n}$ solar cells with an a-Si:H or nc-Si:H intrinsic layer $[3,4]$. To achieve a low absorption loss in the p-layer, the deposition conditions have to be optimized specifically for the thin $(<20 \mathrm{~nm})$ layers to reduce the thickness of the amorphous incubation phase. Another technological issue is that the growth mechanism of nc-Si:H strongly depends on the substrate material and surface conditions thus limiting the choice of transparent conducting oxides for junction cells in a superstrate configuration [5]. Given that $\mathrm{nc}-\mathrm{Si}: \mathrm{H}$ is a heterogeneous material of complex microstructure, the fraction of the crystalline material, the crystallite size, the grain boundaries and voids play a significant role in determining the electronic and optical film properties. These parameters may also have an effect on device performance.

In this paper, we report on electronic, structural, and optical properties of p-type nc-Si thin films deposited by conventional $(13.56 \mathrm{MHz})$ plasma-enhanced chemical vapor deposition

\footnotetext{
*Corresponding author. Tel.: +351 21831 7289; fax: +351218317114.

E-mail address: yvygranenko@deetc.isel.ipl.pt (Y. Vygranenko).
}

(PECVD) and their application for $\mathrm{a}-\mathrm{Si}: \mathrm{H} \mathrm{p}-\mathrm{i}-\mathrm{n}$ photodiodes and solar cells.

\section{Experimental details}

Two series of boron-doped nc-Si:H films were prepared to study their structural and electronic properties. Then, the $\mathrm{p}-\mathrm{i}-\mathrm{n}$ structures with an optimized nc-Si:H p-layer were fabricated. The films and devices were deposited at $150{ }^{\circ} \mathrm{C}$ onto Corning 1737 glass substrates using a multichamber $13.56 \mathrm{MHz}$ PECVD system, manufactured by MVSystems Inc.

The trimethylboron $\left(\mathrm{B}\left(\mathrm{CH}_{3}\right)_{3}\right)$ (TMB), diluted in hydrogen to concentration of $1 \%$, was used as the doping gas. Note that the used notation of doping ratio, [TMB]/[SiH 4$]$, denotes a flow ratio of pure $\mathrm{TMB}$ to $\mathrm{SiH}_{4}$. The first film series (doping series) was deposited at different TMB-to- $\mathrm{SiH}_{4}$ flow ratios in the range from $0.2 \%$ to $1.5 \%$, but keeping the film thickness of about $60 \mathrm{~nm}$. The second film series (thickness series) was deposited at [TMB]/ $\left[\mathrm{SiH}_{4}\right]=1 \%$, but the thickness of the films was varied from 14 to $100 \mathrm{~nm}$. The RF power density, pressure, and hydrogen dilution ratio, $\left[\mathrm{H}_{2}\right] /\left(\left[\mathrm{H}_{2}\right]+\left[\mathrm{SiH}_{4}\right]\right) \times 100 \%$, were fixed at $9 \mathrm{~mW} / \mathrm{cm}^{2}$, $900 \mathrm{mTorr}$, and $99 \%$, respectively.

The $\mathrm{p}-\mathrm{i}-\mathrm{n}$ diodes were fabricated by the following deposition sequence. First, a transparent conducting film with smooth surface was sputtered in $\mathrm{Ar}$ plasma on a $0.5 \mathrm{~mm}$ thick glass substrate using a $2 \mathrm{wt} \% \mathrm{Al}_{2} \mathrm{O}_{3}$ doped $\mathrm{ZnO}$ target. The process was carried out at a pressure of $5 \mathrm{mTorr}$, RF power of $90 \mathrm{~W}$, and a substrate temperature of about $150{ }^{\circ} \mathrm{C}$. A quarter-wavelength 
( $\sim 65 \mathrm{~nm}) \mathrm{ZnO}: \mathrm{Al}$ antireflection coating was used for photodiodes to minimize optical losses, while for collar cells a $700 \mathrm{~nm}$ thick film with a sheet resistance of $\sim 10 \Omega /$ sq. was prepared to reduce the series resistance. Then, a $\mathrm{p}-\mathrm{i}-\mathrm{n}$ stack was deposited over the substrate. Finally, a $\sim 300 \mathrm{~nm}$ thick Al film was sputtered and patterned to form $5 \times 5 \mathrm{~mm}^{2}$ top electrodes.

Two types of devices were fabricated. The first sample was a $\mathrm{p}-\mathrm{i}-\mathrm{n}$ structure with a $20 \mathrm{~nm}$ thick nc-Si:H p-layer. The second sample was a p-p'-i-n structure with a $12 \mathrm{~nm}$ thick nc-Si:H p-layer and $8 \mathrm{~nm}$ thick a-SiC:H p'-layer. The thicknesses of the i- and n-layers were 500 and $20 \mathrm{~nm}$, respectively. For both samples the p-layers were deposited at the same gas mixture of $[\mathrm{TMB}] /\left[\mathrm{SiH}_{4}\right]=1 \%$. The p-type a-SiC:H was deposited using a $\mathrm{SiH}_{4}+\mathrm{H}_{2}+\mathrm{CH}_{4}+\mathrm{TMB}$ gas mixture with a hydrogen dilution ratio of $75 \%,\left[\mathrm{CH}_{4}\right] /\left[\mathrm{SiH}_{4}\right]=1$, and $[\mathrm{TMB}] /\left[\mathrm{SiH}_{4}\right]=1 \%$. The intrinsic a-Si:H was deposited using a $\mathrm{SiH}_{4}+\mathrm{H}_{2}$ gas mixture with a hydrogen dilution ratio of $75 \%$. The n-type a-Si:H material was produced by the addition of $1 \%$ phosphine $\left(\mathrm{PH}_{3}\right)$. The pressure and RF power density were $600 \mathrm{mTorr}$ and $22 \mathrm{~mW} / \mathrm{cm}^{2}$, respectively.

Raman spectroscopy was employed to estimate the crystalline fraction $\left(X_{C}\right)$ of the films deposited on glass. Raman spectra were measured in the back-scattering geometry using a Renishaw micro-Raman spectrometer with a $488 \mathrm{~nm}$ excitation laser line. Transmission and reflection spectra of nc-Si:H films were measured using a UV-vis 2501PC Shimadzu spectrophotometer.

Samples for conductivity measurement were prepared by sputtering coplanar Al electrodes through a shadow mask. A Dektak 8 surface profiler was used for film thickness measurements. Dark conductivity of the films and current-voltage characteristics of the photodiodes were measured at room temperature using a Keithley 4200-SCS semiconductor characterization system.

The spectral response measurements were performed with a PC controlled setup based on an Oriel 77200 grating monochromator, a Stanford Research System SR540 light chopper, and a SR530 DSP lock-in amplifier. The system was calibrated in the spectral range of 300-1100 nm using a Newport 818-UV detector.

\section{Results and discussion}

Fig. 1 shows the Raman spectra of doping and thickness film series. The Raman spectra show a broad shoulder associated with the amorphous phase, and asymmetric band centered at about $517 \mathrm{~cm}^{-1}$, originating from the nanocrystalline phase in the film [6]. A good curve fit was achieved with four Gaussian peaks centered at $440,480,507-511$, and $514-517 \mathrm{~cm}^{-1}$, corresponding to the longitudinal optical (LO) and transverse optical (TO) phonon modes of the amorphous fraction and optical vibrational modes of Si nanocrystals, respectively [7,8].

The crystalline volume fraction, $\boldsymbol{X}_{C}$, was determined using the relation

$X_{C}=I_{c} /\left(I_{c}+\eta I_{a}\right)$,

where $I_{a}$ and $I_{c}$ are the integrated intensities of the peaks centered at 480 , and at $507-517 \mathrm{~cm}^{-1}$, respectively [9]. The ratio of the back-scattering cross-sections, $\eta$, was chosen to be 0.8 [10]. With increasing doping ratio the evaluated crystalline volume fraction decreases from $61 \%$ to $35 \%$ indicating suppression of crystalline growth (see Fig. 1(a)). A similar result has been reported for diborane $\left(\mathrm{B}_{2} \mathrm{H}_{6}\right)$ doped nc-Si:H films deposited by PECVD [11]. For the thickness film series, the crystalline volume fraction increases from $40 \%$ to $51 \%$ in the thickness range $20-60 \mathrm{~nm}$ (see Fig. 1(b)).

Fig. 2 shows the dark conductivity of nc-Si:H films as a function of the $\mathrm{TMB} / \mathrm{SiH}_{4}$ flow ratio. The film conductivity increases with increasing doping ratio, reaches a value of
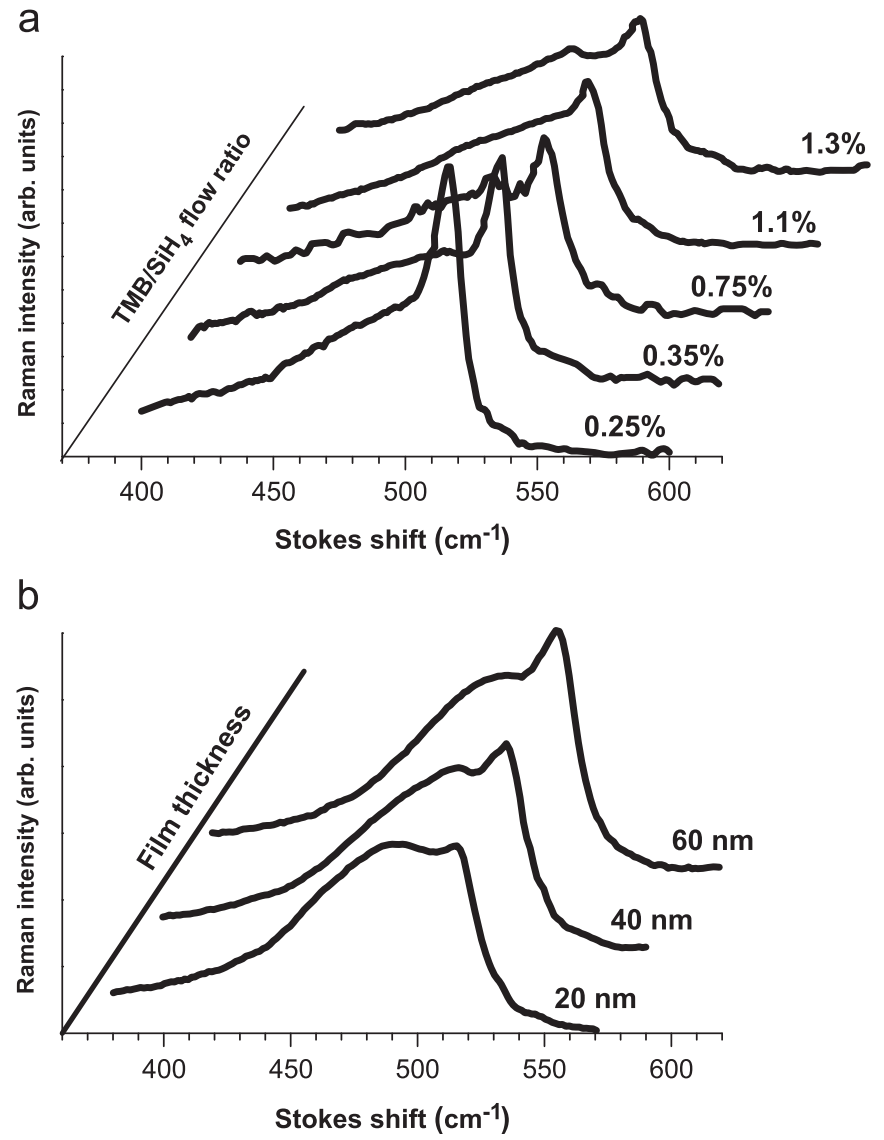

Fig. 1. Raman spectra of nc-Si:H films of (a) doping and (b) thickness series. Samples of doping series are about $60 \mathrm{~nm}$ thick.

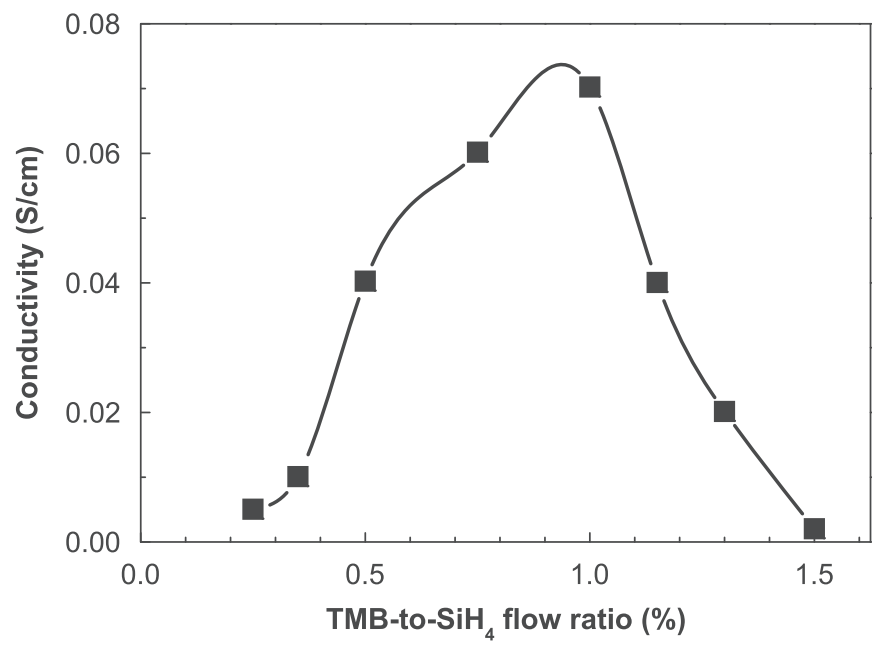

Fig. 2. Conductivity of $60 \mathrm{~nm}$ thick nc-Si:H films as a function of the TMB-to-SiH flow ratio.

$\sim 0.073 \mathrm{~S} / \mathrm{cm}$ at about $1 \%$, and then, gradually decreases down to $0.002 \mathrm{~S} / \mathrm{cm}$ at $1.5 \%$. The conductivity reduction is likely related to an amorphization of the film structure observed in the series of Raman spectra.

Fig. 3 shows a variation of dark conductivity for the thickness series. It is seen that the thin $(<25 \mathrm{~nm})$ films exhibit low conductivity, comparable to that of doped amorphous silicon. For thicker films, the conductivity increases by $2-3$ orders of 


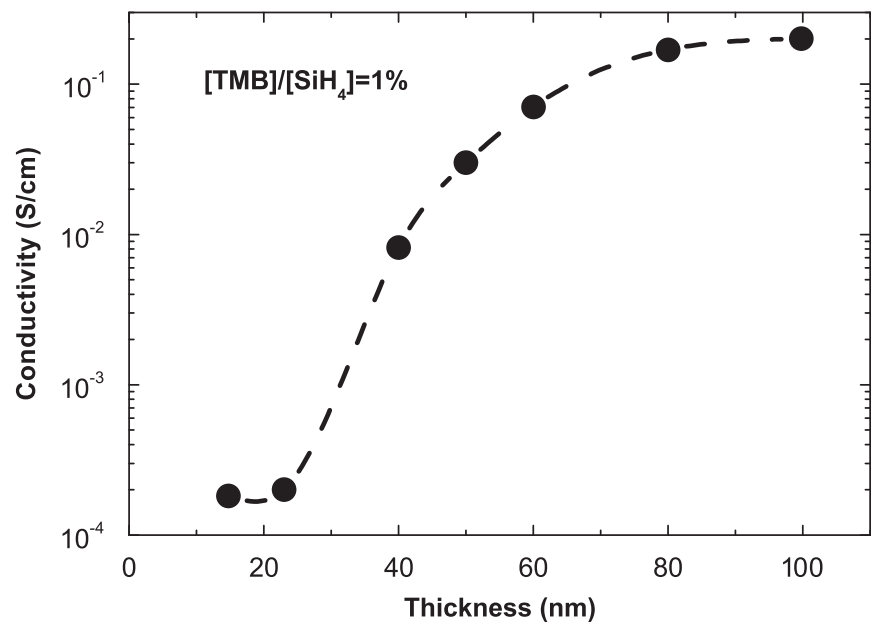

Fig. 3. Variation of conductivity with thickness of nc-Si:H films deposited at the TMB-to- $\mathrm{SiH}_{4}$ flow ratio of $1 \%$.

magnitude in the thickness range from 40 to $80 \mathrm{~nm}$ and then, tends to saturate. For a $100 \mathrm{~nm}$ thick film, the conductivity reaches $0.2 \mathrm{~S} / \mathrm{cm}$. A similar dependence of conductivity on film thickness has been reported for undoped and phosphine-doped nc-Si:H films deposited by PECVD [12]. In Ref. [12], the observed abrupt change in conductivity is explained in terms of percolation theory by destruction of a percolation cluster composed of nanocrystallites as the layer thickness becomes comparable to the size of a crystallite.

To ensure the nanocrystalline film growth on a foreign substrate, and to evaluate the absorption loss in the p-layer of the $\mathrm{p}-\mathrm{i}-\mathrm{n}$ cells, optical measurements were performed on the $22 \mathrm{~nm}$ thick films deposited onto bare glass substrate and onto glass substrate with $\mathrm{ZnO}$ :Al coating. Fig. 4 shows the transmission $(T)$, reflection $(R)$, and absorption $(A=1-T-R)$ spectra of these samples. The transmittance/reflectance curves of the film grown on glass are comparable to the spectra of thin $(\sim 20 \mathrm{~nm})$ nanocrystalline silicon films by VHF PECVD reported elsewhere [13]. The second sample is more transparent because the $\mathrm{ZnO}: \mathrm{Al}$ coating reduces reflectance down to $\sim 20 \%$. The absorption spectra of the samples look similar yielding the absorption loss of $25 \%$ at a wavelength of $400 \mathrm{~nm}$, i.e., both samples are nanocrystalline. The film transparency is better than that for $\mathrm{a}-\mathrm{Si}: \mathrm{H}$ films of the same thickness, what is consistent with deduced Raman crystallinity. Besides, the size of silicon crystallites is believed to be small, and optical gap widening can also be substantial due to quantum size effect [14].

Fig. 5 shows the typical quasi-static current-voltage characteristics of the $\mathrm{p}-\mathrm{i}-\mathrm{n}$ and $\mathrm{p}-\mathrm{p}^{\prime}-\mathrm{i}-\mathrm{n}$ structures. In order to minimize the transient current induced by the trapped charge in the i-layer, the sweep delay was set to $20 \mathrm{~s}$ and the bias voltage was varied at $25 \mathrm{mV}$ increments.

For the $\mathrm{p}-\mathrm{i}-\mathrm{n}$ structure, the $\log$ (current) versus voltage plot is linear in the forward biasing range of $0.4-0.62 \mathrm{~V}$. The diode ideality factor $(n)$ and the saturation current density $\left(J_{o}\right)$ are determined to be 1.63 and $8.6 \mathrm{pA} / \mathrm{cm}^{2}$, respectively. The $\mathrm{p}-\mathrm{p}^{\prime}-\mathrm{i}-\mathrm{n}$ structure shows an exponential dependence of the forward current over five orders of magnitude in the biasing range of $0.2-0.6 \mathrm{~V}$, yielding $n=1.57$ and $J_{o}=440 \mathrm{fA} / \mathrm{cm}^{2}$.

The incorporation of the a-SiC: $\mathrm{H} \mathrm{p}^{\prime}$-layer improves not only the values of $n$ and $J_{o}$, but it also efficiently suppresses the leakage current. The reverse dark current of the $\mathrm{p}-\mathrm{i}-\mathrm{n}$ structure saturates at about $100 \mathrm{nA} / \mathrm{cm}^{2}$. The $\mathrm{p}-\mathrm{p}^{\prime}-\mathrm{i}-\mathrm{n}$ structure shows a significantly lower leakage in the low bias range. Here, the current density of

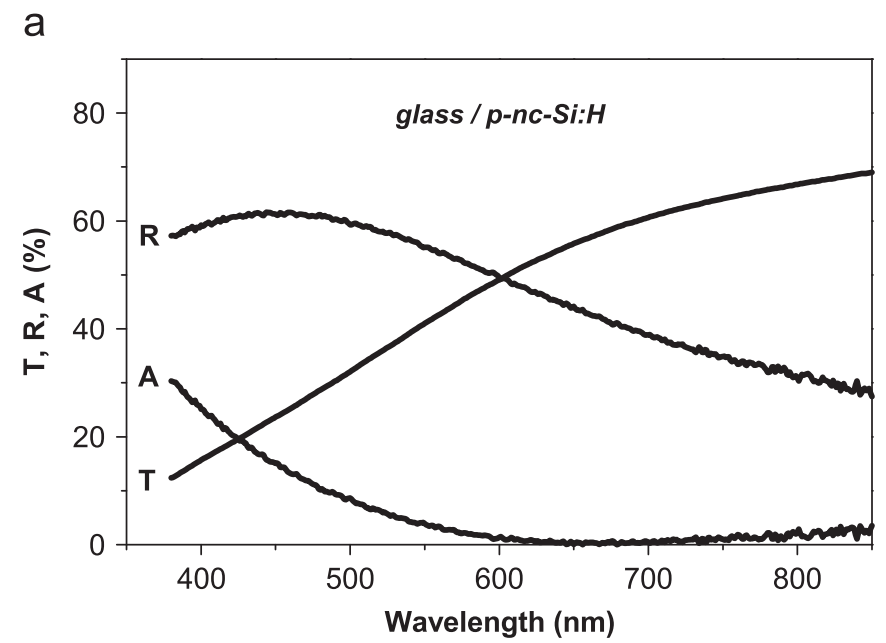

b

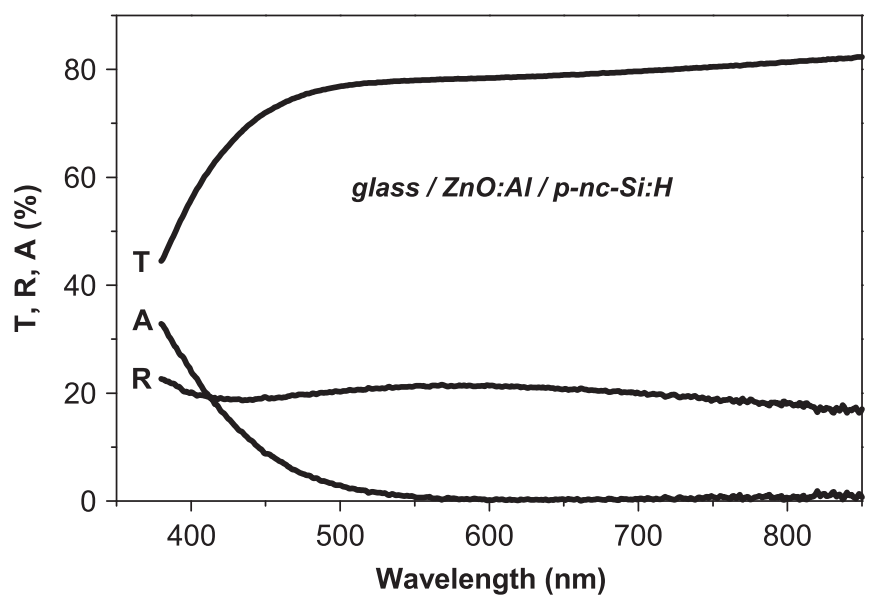

Fig. 4. Transmission, reflection, and absorption spectra of thin $(22 \mathrm{~nm}) \mathrm{nc}-\mathrm{Si}: \mathrm{H}$ film on (a) glass substrate and (b) glass with $\mathrm{ZnO}$ :Al coating.

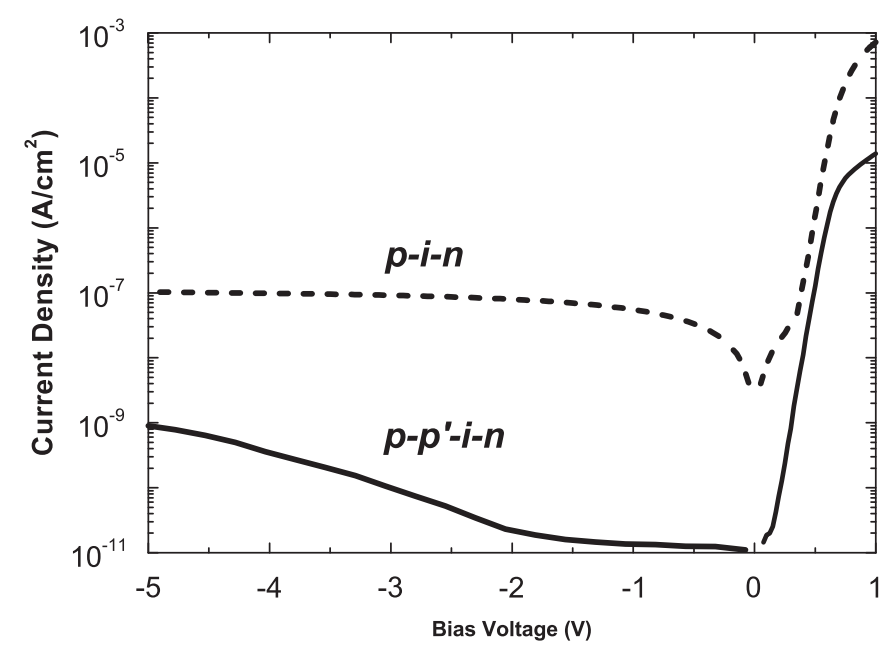

Fig. 5. Dark current-voltage characteristics of the $\mathrm{p}-\mathrm{i}-\mathrm{n}$ and $\mathrm{p}-\mathrm{p}^{\prime}-\mathrm{i}-\mathrm{n}$ structures.

$16 \mathrm{pA} / \mathrm{cm}^{2}$ at $-1 \mathrm{~V}$ is comparable to that reported for state-ofthe-art a-Si:H photodiodes [15]. At reverse biases higher than $2 \mathrm{~V}$, when the $\mathrm{p}^{\prime}$-i-layers are fully depleted and the depletion region expands into the nc-Si:H p-layer, the leakage current increases near exponentially, reaching the value of $4 \mathrm{nA} / \mathrm{cm}^{2}$ at $-5 \mathrm{~V}$. 


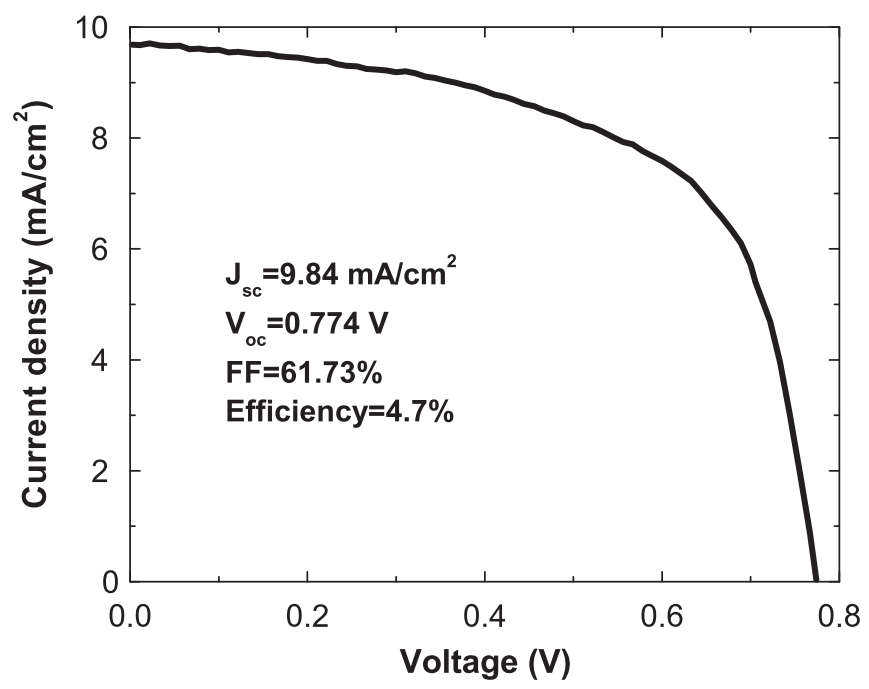

Fig. 6. Current-voltage characteristics of the p-i-n cell under 1.5 AM illumination.

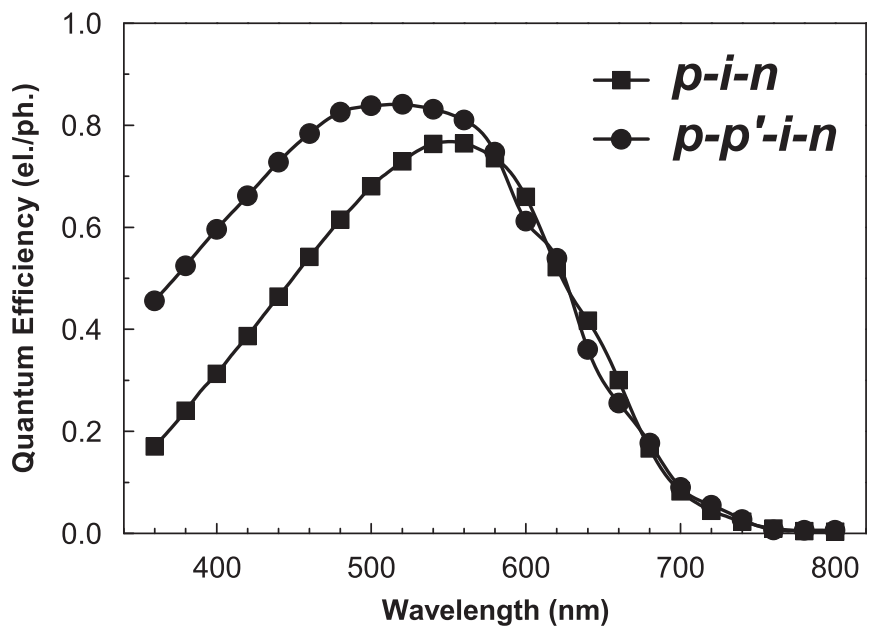

Fig. 7. Spectral response characteristics of the $\mathrm{p}-\mathrm{i}-\mathrm{n}$ and $\mathrm{p}-\mathrm{p}^{\prime}-\mathrm{i}-\mathrm{n}$ structures.

Fig. 6 shows the current-voltage characteristics of the $p-i-n$ cell with a $700 \mathrm{~nm}$ thick $\mathrm{ZnO}$ :Al layer under $1.5 \mathrm{AM}$ illumination. The solar cell shows a short-circuit current density of $9.84 \mathrm{~mA} / \mathrm{cm}^{2}$, an open-circuit voltage of $774 \mathrm{mV}$, a fill factor of $61.73 \%$, and an efficiency of $4.7 \%$. The achieved device performance is lower than that for state-of-the-art a-Si:H p-i-n solar cells because of the recombination losses at the heterojunction $\mathrm{p}-\mathrm{i}$ interface.

Fig. 7 shows the spectral response characteristics of the $\mathrm{p}-\mathrm{i}-\mathrm{n}$ and $\mathrm{p}-\mathrm{p}^{\prime}-\mathrm{i}-\mathrm{n}$ structures. The measurements were performed under short-circuit conditions without background illumination. The external quantum efficiency of the p-p'-i-n structure reaches a peak value of $84 \%$ at a $520 \mathrm{~nm}$ wavelength. Its blue response is mainly limited by the absorption losses in the $\mathrm{p}$ - $\mathrm{p}^{\prime}$-layers. The deterioration in the short-wavelength response of the $\mathrm{p}-\mathrm{i}-\mathrm{n}$ structure is attributed to the recombination losses at the heterojunction $\mathrm{p}-\mathrm{nc}-\mathrm{Si}: \mathrm{H} / \mathrm{i}-\mathrm{a}-\mathrm{Si}: \mathrm{H}$ interface.

Thus, the incorporation of the $\mathrm{p}^{\prime}$-layer is crucial for low leakage, blue-enhanced $p-p^{\prime}-i-n$ photodiodes. The role of the buffer layer is discussed in prior reports on the development of a-Si:H p-i-n solar cells with an nc-Si:H p-layer [16]. In the photovoltaic mode, the buffer effectively blocks electron back diffusion due to the large band offset between the a-Si:H i-layer and the nc-Si:H p-layer and reduces the recombination loss at the front contact [17].

\section{Conclusions}

The influence of boron doping and layer thickness on the structural and electronic properties of nc-Si:H films grown by PECVD has been systematically studied. The film crystallinity and conductivity were found to be tailored by controlling the TMB-to$\mathrm{SiH}_{4}$ ratio. For $60 \mathrm{~nm}$ thick films, the conductivity of $0.07 \mathrm{~S} / \mathrm{cm}$ was achieved at a doping ratio of $\sim 1 \%$. It was also found that conductivity of the thin ( $<25 \mathrm{~nm}$ ) film was limited by a chargecarrier transport through an a-Si:H network, while in the thicker layers, the observed conductivity enhancement was ascribed to the formation of a percolation cluster composed of Si nanocrystallites. By employing the $\mathrm{p}^{+} \mathrm{nc}-\mathrm{Si}: \mathrm{H}$ as a window layer, complete $\mathrm{p}-\mathrm{i}-\mathrm{n}$ structures were fabricated. Low leakage current and enhanced sensitivity in the UV/blue range were achieved by incorporating an a-SiC:H buffer between the p- and i-layers.

\section{Acknowledgments}

The authors are grateful to the Portuguese Foundation of Science and Technology through fellowship BPD20264/2004 for financial support of this research, and to the Giga-to-Nanoelectronics Centre at the University of Waterloo for providing necessary equipment and technical help to carry out this work.

\section{References}

[1] S.A. Filonovich, H. Aguas, I. Bernacka-Wojcik, C. Gaspar, M. Vilarigues, L.B. Silva, E. Fortunato, R. Martins, Highly conductive p-type nanocrystalline silicon films deposited by RF-PECVD using silane and trimethylboron mixtures at high pressure, Vacuum 83 (2009) 1253-1256.

[2] H. Chen, M.H. Gullanar, W.Z. Shen, Effects of high hydrogen dilution on the optical and electrical properties in B-doped nc-Si:H thin films, J. Cryst. Growth 260 (2004) 91-101.

[3] A.V. Shah, J. Meier, E. Vallat-Sauvain, N. Wyrsch, U. Kroll, C. Droz, U. Graf, Material and solar cell research in microcrystalline silicon, Sol. Energy Mater. Sol. Cells 78 (2003) 469-491.

[4] M. Kondo, A. Matsuda, Low-temperature fabrication of nanocrystallinesilicon solar cells, in: Y. Hamakawa (Ed.), Thin-film Solar Cells, Springer2004, pp. 139-148.

[5] T. Fujibayashi, M. Kondo, Roles of microcrystalline silicon $p$ layer as seed, window, and doping layers for microcrystalline silicon $p-i-n$ solar cells, J. Appl. Phys. 99 (2006) 043703.

[6] C. Smit, R.A.C.M.M. van Swaaij, H. Donker, A.M.H.N. Petit, W.M.M. Kessels, M.C.M. van de Sanden, Determining the material structure of microcrystalline silicon from Raman spectra, J. Appl. Phys. 94 (2003) 3582-3588.

[7] H. Xia, Y.L. He, L.C. Wang, W. Zhang, X.N. Liu, X.K. Zhang, D. Feng, H.E. Jackson, Phonon mode study of $\mathrm{Si}$ nanocrystals using micro-Rama spectroscopy, J. Appl. Phys. 78 (1995) 6705-6708.

[8] S. Zhang, X. Liao, Y. Xu, R. Martins, E. Fortunato, G. Kong, The diphasic nc-Si/a$\mathrm{Si}: \mathrm{H}$ thin film with improved medium-range order, J. Non-Cryst. Solids 338-340 (2004) 188-191.

[9] E. Bustarret, M.A. Hachicha, M. Brunel, Experimental determination of the nanocrystalline volume fraction in silicon thin films from Raman spectroscopy, Appl. Phys. Lett. 52 (1988) 1675-1677.

[10] A.T. Vautsas, M.K. Hatalis, J.B. Boyce, A. Chiang, Raman spectroscopy of amorphous and microcrystalline silicon films deposited by low-pressure chemical vapor deposition, J. Appl. Phys. 78 (1995) 6999-7006.

[11] R. Saleh, N.H. Nickel, Raman spectroscopy of B-doped microcrystalline silicon films, Thin Solid Films 427 (2003) 266-269.

[12] V.G. Golubev, L.E. Morozova, A.B. Pevtsov, N.A. Feoktistov, Conductivity of thin nanocrystalline silicon films, Semiconductors 33 (1999) 66-69.

[13] A. Gordijn, J. Loffler, W.M. Arnoldbik, F.D. Tichelaar, J.K. Rath, R.E.I. Schropp, Thickness determination of thin $(\sim 20 \mathrm{~nm})$ microcrystalline silicon layers, Sol. Energy Mater. Sol. Cells 87 (2005) 445-455.

[14] Z. Hu, X. Liao, H. Diao, Y. Cai, S. Zhang, E. Fortunato, R. Martins, Hydrogenated p-type nanocrystalline silicon in amorphous silicon solar cells, J. Non-Cryst. Solids 352 (2006) 1900-1903.

[15] J.A. Theil, Leakage current behavior in common i-layer a-Si:H p-i-n photodiode arrays, Mater. Res. Soc. Symp. Proc. 762 (2003) 205-210.

[16] J.K. Rath, R.E.I. Schropp, Incorporation of p-type microcrystalline silicon films in amorphous silicon based solar cells in a superstrate structure, Sol. Energy Mater. Sol. Cells 53 (1998) 189-203.

[17] N. Palit, P. Chatterjee, Computer analysis of a-Si p-i-n solar cells with a hydrogenated microcrystalline silicon $p$ layer, J. Appl. Phys. 86 (1999) 6879-6889. 